\title{
A RECENT SPRUCE BUDWORM OUTBREAK IN THE LOWER ST. LAWRENCE AND GASPE PENINSULA WITH REFERENCE TO AERIAL SPRAYING OPERATIONS ${ }^{1}$
}

\author{
By J. R. BLAIS and R. MARTINEAU ${ }^{2}$
}

René Martineau obtained a B.Sc. in Forestry from Laval University in 1939, an M.Sc. in Entomology from the University of Illinois in 1941 and an M.F. from Yale University in 1944. He obtained his licence as a Quebec Land Surveyor in 1950. In 1939 he joined the staff of the Bureau of Forest Entomology, Forest Protection Service, Province of Quebec; since 1952 he has been in charge of special Insect Surveys for the Forest Biology Laboratory of the Canadian Department of Agriculture, Quebec.

\section{$A B S T R A C T$}

The main topics discussed in this paper are: the progress of the spruce budworm outbreak in the Lower St. Lawrence-Gaspé regions from 1949 to 1956; the areas sprayed between 1954 and 1958; timing of spray application in relation to insect abundance and developnent; effects of treatment on spruce budworm populations and on defoliation of balsam fir; results of aerial defoliation surveys and egg surveys; estimated amounts of wood destroyed by the insect, and losses averted through spraying; the various natural control factors associated with the decline and the eventual collapse of the outbreak.

\section{INTRODUCTION}

A spruce budworm outbreak began in northern New Brunswick and adjoining parts of Quebec about 1949. In Quebec, the collapse of the outbreak was complete by 1958, (Blais and Martineau, 1958) but was still active in a relatively small area in central New Brunswick (Webb et al, 1959). For the first time in the history of such outbreaks in eastern Canada, the aerial application of insecticides was practised on a large scale in an effort to reduce the damage caused to pulpwood stands by this insect. In conjunction with the spraying operations, defoliation and insect population surveys were conducted throughout the outbreak area for many years. These surveys furnished valuable information on the history of the outbreak as well as providing a yearly appraisal of population fluctuations in sprayed and unsprayed areas.

Events in New Brunswick, for the period 1952-56, have been discussed by Webb (1958). The present paper will deal exclusively with the situation as it existed in Quebec.

Progress of the infestation in eastern Quebec is shown in Figure 1. Defoliation was first noticed in 1949 in the southern section of the Lower St. Lawrence and spread rapidly, mostly in an easterly direction. In 1950 and 1951 separate foci developed in a number of localities along the south and the north shores of the Gaspé Peninsula, but soon joined to form one continuous area of infestation. By 1956 the outbreak had reached its ultimate boundaries and

\footnotetext{
'Contribution No. 642, Forest Biology Division, Research Branch, Department of Agriculturc, Ottawa, Canada. Cost of publication shared by Forest Biology Division and the C.I.F.

"Forest Biology Laboratory, Quebec, Que. Biographical reference for Dr. J. R. Blais, Iror. Cliron. 33.
} 
covered approximately 14,000 square miles. In the summer of 1956 insect numbers began to decline and continued to do so until the infestation came to an end in 1958.

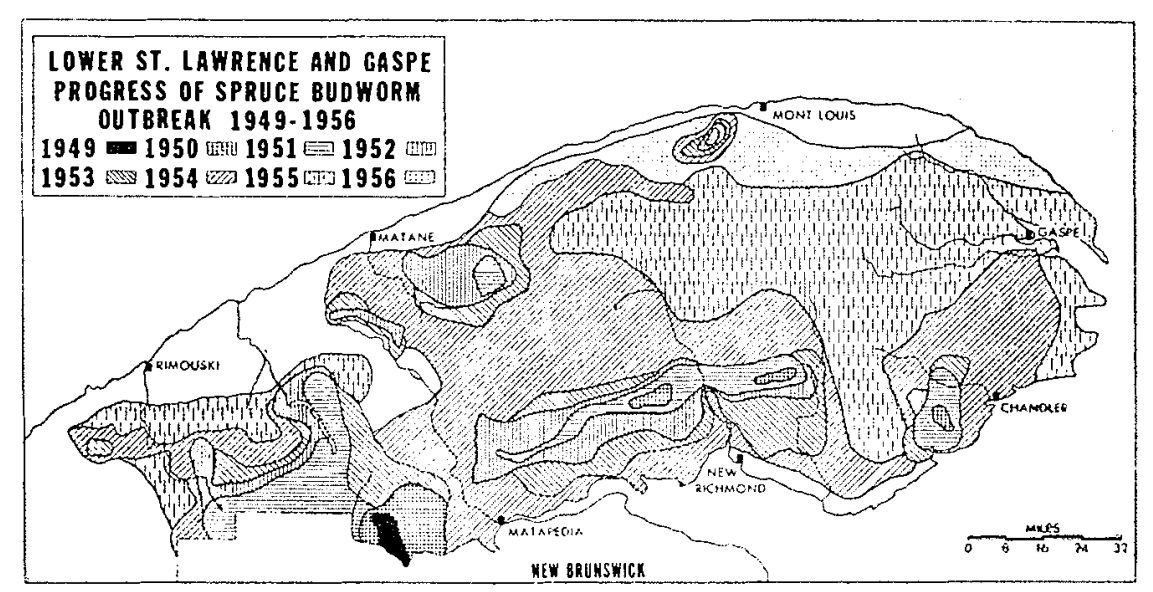

FIGURE 1. Progress of spruce budworm outbreak 1949-1956.

Aerial spraying operations commenced in 1954 in this region and were continued each year until 1958. The approximate acreage treated each year in Quebec was: 1954, 318,000 acres; 1955, 1,040,000 acres; 1956, 442,000 acres; $1957,1,255,000$ acres, and 797,000 acres in 1958 for a total of $3,852,000$ acres.

Of the total operational area, 627,000 acres or 16 per cent was sprayed twice and a negligible amount sprayed three times. The territories treated, from 1954 to 1958, in the Lower St. Lawrence and Gaspé are shown in Figure 2.

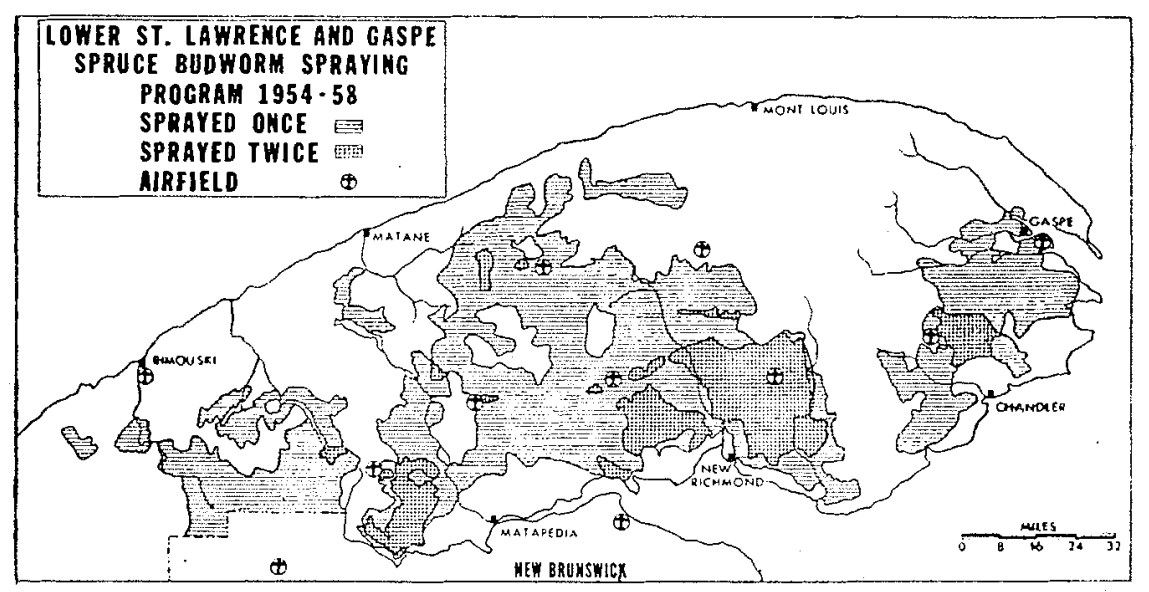

FIGURE 2. Spruce budworm spraying program. 
The organizational and physical aspects of the spraying operations in Quebec have been discussed by Côté (1958). The present paper deals chiefly with the biological aspects of the situation, the progress of the outbreak, the effects of the spraying operations, and the apparent causes of its decline. Timing of operations, assessment of immediate results, defoliation and damage surveys, and the hazard rating for future operations were supervised by L. Daviault for the 1954 operations and were the responsibility of the senior author from 1955 to 1958; the egg survey was under the supervision of the junior author from 1953 to 1958 .

\section{Timing of Operations}

The success of each year's operation depended to a considerable degree on applying the insecticide at the appropriate time, in relation to insect development. In the early part of the season the small larvae are concealed in needles or buds and are less vulnerable to the sprays than later when they are larger and more exposed as a result of bud flaring. When the spray was applied early in relation to insect development, more of the current year's foliage was saved, but fewer insects were killed than when it was applied after feeding had progressed for some time. Most areas responded well to the treatment when applied during the fourth and early fifth larval instars. When past defoliation had been severe, greater emphasis was placed on saving the current year's growth and an attempt was made to spray early in relation to insect development, but where insect populations were moderate or low (less than 15 larvae per 18-inch branch tip), spraying could profitably be delayed.

Since timing of operations depended on both insect development and abundance, sampling of populations took place in the pre-spray period in as many localities as possible in or near areas to be treated. Between 75 and 130 localities were sampled during this pre-spray survey for each of the last three years of operation. Samples consisted of one 18-inch branch tip, obtained by means of pole-pruners from the mid-crown of each of five co-dominant balsam fir trees. The branches were carefully examined at a field laboratory and all spruce budworms recorded and classified as to instar.

In addition to determining insect development by means of ground surveys, aerial surveys covering all areas to be treated were conducted at low altitude for the purpose of assessing balsam fir shoot growth, a good criterion of larval development (Webb, 1955). Aerial surveys were especially useful for determining insect development in less accessible areas.

Owing to the wide range in geography and topography of the region under discussion, insect development varied considerably between sectors. Within the same year, there could be a difference of three weeks in the development of insects at low and high elevations, a range of 4,000 feet in this area. Development could also differ markedly between the eastern and western sectors. The relationship between one area and the next varied considerably between years so that a phenological map for any one year could not be relied upon for future years. For instance, in 1955, an unusually warm and dry year, larval development at Metis Lake in the Lower St. Lawrence was two weeks ahead of that at Pabos River in the Gaspé. In 1957, a cool wet year, insect development at Pabos River was a few days ahead of that at Metis Lake. 
The latter locality, being in the interior and away from the tempering effects of the ocean, is much more subject to the yearly variations in spring temperatures than Pabos River in the eastern part of the Peninsula where maritime climatic conditions prevail.

Development in the spring was also strongly dependent on the accumulation of winter snows since melting snow depresses local temperatures. Development was retarded in areas of deep snow and accelerated where the ground was freed early of the snow cover. This situation was especially striking in 1958 when relatively little snow had fallen on the Grande Cascapedia River watershed while snowfall had been heavy on the watersheds of the Nouvelle River to the west and the Bonaventure River to the east. Although these watersheds are contiguous and the general topography in all three is very similar, phenological events in early June in the Grande Cascapedia watershed were ahead of events in the other two watersheds by approximately one week.

Since application of the insecticide depended so much on favourable weather and since insect development was sometimes synchronized over relatively large discontinuous areas, all stands could not be treated at optimum time. However, much to the credit of the spraying organization, spray application was completed prior to insect pupation in all five years of operation. The amount of foliage saved each year, as discussed later, was a criterion of the good or poor timing of spray application.

Eppects of Spraying on Spruce budworm Populatrons AND ON DEFolitation

Each year the effect of the current and of the previous years' operations was determined by comparing residual populations and degree of defoliation of the current year's growth in sprayed and adjacent unsprayed areas. All localities visited during the pre-spray survey were re-sampled plus an additional number of new localities amounting to a total of approximately 225 localities in all for each year. This post-spray survey was made at the time of the late pupal stage. The number of trees sampled and the number of branches obtained from each locality were the same as that previously described for the pre-spray survey. In the localities visited at the time of both surveys, samples were always obtained from the same trees. During the post-spray survey, in addition to counting the number of budworms for each branch obtained, defoliation of the current year's growth was classified in the following percentages: $0,10,25,50,75,90$ and 100 .

In 1954, the efficacy of the sprays with respect to number of insects killed was determined from observations on a few permanent sample plots and populations were measured on a branch-area basis rather than on the 18-inch branch tip adopted in subsequent years. Consequently, results for 1954 cannot readily be compared with other years. Nevertheless the effects of the treatment that year appear to have been very similar to those obtained in later years. Table 1 gives the average defoliation and residual population for sprayed and unsprayed localities, the percentage of foliage saved, and percentage of insects killed by the sprays from 1955 to 1958 as determined by the post-spray surveys. Since, in the second year after treatment, there usually was no difference in the number of insects and in the amount of defoliation of 
TABLE 1

Average Defoliation and Residual population for Sprayed and Unsprayed localities; Per Cent foliage Saved, and Per Cent INSECTS KILLED BY THE SPRAYS 1955-58

\begin{tabular}{|c|c|c|c|c|c|c|}
\hline Year & Treatment & $\begin{array}{l}\text { No. of } \\
\text { localities } \\
\text { sampled }\end{array}$ & $\begin{array}{c}\text { Av. \% } \\
\text { defoliation } \\
\text { of current } \\
\text { year }\end{array}$ & $\begin{array}{l}\% \text { foliage } \\
\text { saved by } \\
\text { spraying }\end{array}$ & $\begin{array}{l}\text { Av. No. } \\
\text { of insects } \\
\text { per 18-inch } \\
\text { branch }\end{array}$ & $\begin{array}{l}\text { \% reduction } \\
\text { in population } \\
\text { by spraying }\end{array}$ \\
\hline \multirow[t]{3}{*}{1955} & Unsprayed & 98 & 69 & - & 2.79 & - \\
\hline & Sprayed 1955 & 108 & 26 & 43 & 0.31 & 89 \\
\hline & Sprayed 1954 & 19 & 12 & 57 & 1.80 & 36 \\
\hline \multirow[t]{3}{*}{$\overline{1956}$} & Unsprayed $^{2}$ & 112 & 84 & 二 & 6.47 & - \\
\hline & Sprayed 1956 & 52 & 37 & 47 & 0.51 & 92 \\
\hline & Sprayed 1955 & 54 & 17 & 67 & 2.29 & 65 \\
\hline \multirow[t]{3}{*}{$1957^{2}$} & Unsprayed $^{2}$ & 88 & 76 & - & 3.22 & 二 \\
\hline & Sprayed 1957 & 59 & 58 & 18 & 0.61 & 81 \\
\hline & Sprayed 1956 & 15 & 33 & 43 & 1.38 & 56 \\
\hline \multirow[t]{3}{*}{1958} & Unsprayed $^{1}$ & $\overline{141}$ & 6 & - & 0.04 & - \\
\hline & Sprayed 1958 & 54 & 4 & 2 & 0.03 & 25 \\
\hline & Sprayed 1957 & 47 & 2 & 4 & 0.01 & 75 \\
\hline
\end{tabular}

Includes some localities sprayed two years or more previously.

Excluding localities in the region of the Shickshock Mountains (sec text).

the current year's growth between sprayed and unsprayed localities, data from localities sprayed two years or more prior to a given year were included with data from unsprayed localities. As a consequence of unfavourable weather in 1956, populations were drastically reduced the following year in the region of the Shickshock Mountains (Blais, 1958a). For this reason, the population data obtained in 1957 from this region, which represents approximately 12 per cent of the area under infestation, were not included with data for the remainder of the study area where the infestation was still active.

In 1955 and 1956 , close to 90 per cent of the larvae were killed by the sprays, and in 1957, 81 per cent. In 1958, the effects of the operations were eclipsed by the collapse of the outbreak, and the 25 per cent reduction in population attributable to spraying is of little significance. The amount of foliage saved in 1955 and 1956 was slightly less than 50 per cent, but in 1957 it amounted to only 18 per cent. This was largely due to unfavourable weather which delayed operations that spring; during one third of the spraying period, weather conditions completely prohibited operations and seriously curtailed them on a number of other days. With the collapse of the outbreak in 1958, defoliation was very light in both sprayed and unsprayed localities and the amount of foliage saved by spraying was negligible. The difference in defoliation between sprayed and unsprayed areas was evident the year of treatment, but was even more so the following year. Although the current year's growth was less severely defoliated in localities sprayed the previous year than in the currently sprayed ones, the insect populations indicate that reinvasion of the sprayed territories was already evident the year following treatment. It was usually necessary to respray two to three years after treatment. 
It occasionally happened that a successfully treated area was repopulated the year of treatment as a result of the influx of adults from surrounding untreated territories. It is known that moths may be transported by convectional and turbulent air currents for long distances (Henson, 1951; Greenbank, 1957). Such invasions took place in 1955 in the Lake Matane and in 1957 in the Pabos River areas. The localities sampled in these regions at the time of the post-spray survey indicated a pronounced reduction in the number of budworms, yet, at the time of the egg-mass survey, populations were high. Since the local populations reduced by the insecticide could not give rise to large numbers of eggs, part of the egg-masses were evidently laid by adults coming from outside. Light traps in operation in the immediate vicinity of Matane Lake in 1955 indicated very high catches for one or two nights and confirmed the influx of moths into the area. These two regions had to be resprayed the following year in order to save the trees.

\section{Egg Survey}

An egg-mass survey was conducted along nearly all passable roads in the study area from 1953 to 1958 , by members of the Federal and Provincial governments and of woods industries. Between 600 and 650 localities were sampled each year according to the sequential sampling technique developed by Morris (1954). An appreciation of the coverage obtained by this survey can be gained from Figure 3 which shows the location of the points sampled in 1956. A classification of the average number of egg-masses per 100 square feet of foliage for each locality sampled was based on the degree of defoliation expected in the subsequent year, and was made according to the following:

$\begin{array}{lc}\text { Class } & \text { No. of egg-masses per } \mathbf{1 0 0} \text { sq. } \mathbf{f t} \text {. of foliage } \\ \text { light } & 0-99 \\ \text { moderate } & 100-239 \\ \text { severe } & 240 \text { and over }\end{array}$

At each locality visited, records were made of current and of past defoliation. These records were very useful in verifying observations made from the air.

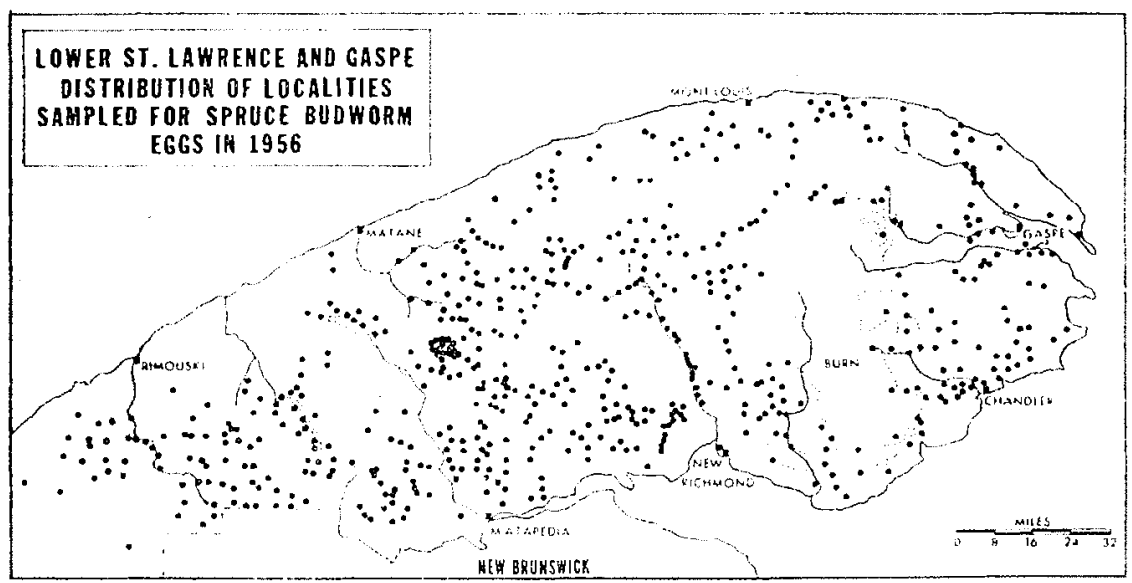

FIGURE 3. Distribution of localities sampled for eggs in 1956. 
Results of the egg survey showed that populations were greater in unsprayed than in sprayed areas (Table 2). Except for the last two years of the outbreak, the beneficial effects of the treatment were most apparent in the currently sprayed areas; in areas sprayed one year before the survey, the number of eggs was less than in unsprayed areas but generally greater than in the currently sprayed ones, indicating a gradual resurgence in such areas. Conditions in localities sprayed two years or more prior to the year of survey no longer differed from unsprayed localities with respect to numbers of eggs. The data in Table 2 clearly demonstrate the beginning of the population decline in 1957, and the collapse of the outbreak in 1958. In 1957 and 1958, eggs appeared to be less numerous in localities sprayed one year prior to the year of survey than in the currently sprayed localities. This was probably not an effect of spraying, but rather a consequence of the erratic decline of populations through natural control factors discussed later.

\section{Damage to Forest Stands}

Defoliation and Tree Mortality as Determined by Aerial Surveys

Each year, from 1953 to 1958 , an aerial defoliation and damage survey was conducted on completion of feeding, usually in late July and early

\section{TABLE 2}

Number of Localities Sampled for EgGs and the Average Number of EgG-Masses per 1,000 Square Feet of Branch-Surface por Areas Differing in Spraying History for Each Year of Study

\begin{tabular}{|c|c|c|c|c|c|}
\hline Year & Treatment & $\begin{array}{c}\text { No. of } \\
\text { localities }\end{array}$ & \multicolumn{3}{|c|}{$\begin{array}{l}\text { Av. No. of egg-masses per } 1,000 \\
\text { square feet of branch-surface }\end{array}$} \\
\hline 1953 & Unsprayed & 400 & 3,181 & & \\
\hline \multirow[t]{2}{*}{$\overline{1954}$} & Unsprayed & 526 & 1,580 & & \\
\hline & Sprayed 1954 & 80 & \multicolumn{3}{|c|}{524} \\
\hline \multirow[t]{3}{*}{1955} & Unsprayed & 469 & 2,456 & \multirow{3}{*}{634} & \\
\hline & Sprayed 1955 & 130 & & & \\
\hline & Sprayed 1954 & 57 & & & 1,055 \\
\hline \multirow[t]{3}{*}{1956} & Unsprayed $^{\mathrm{I}}$ & $\overline{446}$ & 2.887 & \multirow{3}{*}{1,949} & \\
\hline & Sprayed 1956 & 56 & & & \\
\hline & Sprayed 1955 & 110 & & & 2,059 \\
\hline \multirow[t]{3}{*}{1957} & Unsprayed $^{1}$ & 445 & 869 & \multirow{3}{*}{520} & \\
\hline & Sprayed 1957 & 141 & & & \\
\hline & Sprayed 1956 & 41 & & & 127 \\
\hline \multirow[t]{3}{*}{1958} & Unsprayed $^{1}$ & 375 & 19 & \multirow{3}{*}{\multicolumn{2}{|c|}{8}} \\
\hline & Sprayed 1958 & 64 & & & \\
\hline & Sprayed 1957 & 115 & & & \\
\hline
\end{tabular}

IIncludes some localicies sprayed two or more years previously.

August. During 1953 and 1954, only general reconnaissance surveys were conducted with special attention being given to infested regions, but after 1954 the survey followed a more rigid system. Observations were made at intervals of 30 seconds along parallel lines three miles apart at an altitude of about 500 feet and at a speed of 90 miles per hour. At each observation where- 
ever balsam fir stands occurred, defoliation of the current year's and of past growth was recorded.

At all times in the course of the aerial surveys there were two observers in the plane, one recording on a map the course followed, the second recording defoliation estimates with reference to specific points marked on the map. Special attention was given to areas where balsam fir mortality had occurred and many of these areas were revisited and their contours accurately mapped from higher altitudes. The whole forested area in the Lower St. Lawrence and Gaspé Peninsula was surveyed in this manner between 1955 and 1957. In 1958, since only light defoliation occurred throughout all infested regions, the aerial survey was conducted on a general reconnaissance basis although special attention was given to the mapping of mortality areas. Each year extensive observations were made from the ground to confirm estimates of defoliation of the current year's and of past growth obtained through the aerial survey.

Spruce budworm feeding is largely confined to the current year's growth. It is the repeated destruction of the annual shoot growth that eventually kills the trees. In the course of an outbreak most stands exhibit two categories of defoliation, that inflicted on the current growth by the current insect population, and that which is the accumulated result of the feeding of past years. Defoliation for both current and past growth was recorded as light, moderate, or severe. In the case of the current year's growth, defoliation was based on the degree of reddish-brown colour of the tree crowns. This colour results from the adherence to the branches of debris composed of partially eaten needles and of insect frass. The debris is readily washed off by rains but usually persists for a few weeks. Defoliation of past growth was based on the degree of greyness of the stands. The general appearance of the bare lichen-covered twigs and branches of severely defoliated stands contrasts strongly with the solid green of healthy stands. Trees appearing as completely grey were considered to be dying or dead.

From 1953 to 1956 , although defoliation of the current year's growth varied for different regions there were extensive areas where a specific degree of defoliation was uniform. In 1957, however, defoliation of the current year's growth was extremely variable, and many degrees of defoliation were found within relatively small areas, indicating that insect distribution was more erratic that year. It is significant that 1957 marked the beginning of the infestation's decline throughout the region. In 1958, defoliation of the current year's growth was so light that is was noticeable only in a very restricted area in the Rimouski River watershed.

With respect to differences in defoliation between sprayed and unsprayed areas, the aerial surveys confirmed the results obtained by the ground surveys discussed earlier. The amount of foliage saved although apparent the year of treatment was even more so the following year, while severe defoliation usually recurred the second year after treatment.

Each year, all infested territories were given a hazard rating which served as a basis for the following year's spraying operations. This rating was established by means of the defoliation and egg population records. Treatment was 
usually applied to territories where any' further severe defoliation would almost certainly result in tree mortality. During the first two years of operation treatment was recommended for stands where the current year's growth had been severely attacked for three to four years, and where, on the basis of the number of eggs present, serious defoliation could again be expected the following year. After 1955, two to three years of severe defoliation was considered as sufficiently critical to warrant spraying when further severe defoliation was anticipated.

Tree mortality as a result of repeated defoliation was first noticed in the western and central sectors of the area in 1955. Two years later, mortality was apparent in varying degrees in many sectors of the Lower St. Lawrence and Gaspé. In some areas only scattered trees were dead, while in others more or less solid blocks of dead trees occurred varying from a few to several hundred acres. The irregular distribution of dead trees made it difficult to assess the amount of mortality over extensive regions. The following broad classifications were used to denote the dead timber of merchantable size for the various areas where mortality occurred: 1 to 10 per cent, 11 to 24 per cent, and 25 per cent plus (Fig. 4). In the Lower St. Lawrence region tree mortality occurred indiscriminately in the valleys or on hill tops, while in the Gaspe Peninsula the dead timber was almost invariably found on the high plateaux on the south shore, and in the valleys on the north shore. As might be expected, tree mortality was most prevalent where defoliation had persisted for the longest period of time.

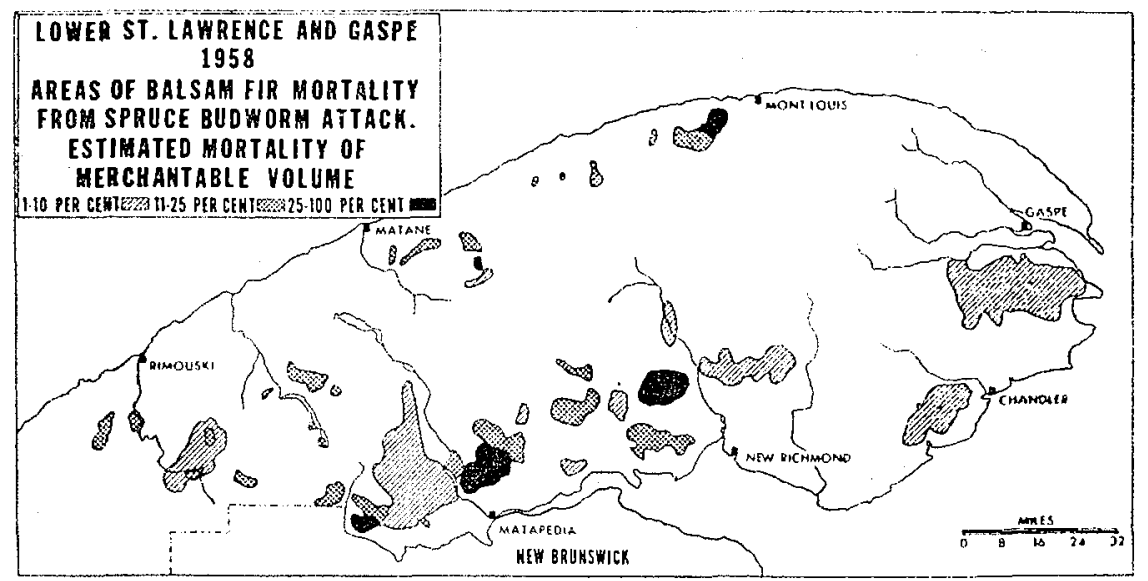

FIGURE 4. Areas and estimated merchantable volume of balsam fir mortality.

In 1957, the actual amount of tree mortality was ascertained from two areas that appeared grey from the air and which were located some 15 miles apart on the Nouvelle River watershed. In each of the two stands all living and dead trees two inches d.b.h. and over were tallied for a width of 33 feet over a length of 20 chains. Balsam fir formed a high proportion of the tree components in these stands with paper birch and white spruce present in small 
quantities. Over 75 per cent of the balsam fir trees were killed as a result of spruce budworm defoliation in each of these stands. Whether the degree of mortality in these two stands was typical of that existing in other areas was difficult to confirm, because although areas where mortality occurred were fairly common, many were inaccessible while those easy of access were being exploited to salvage the dead timber.

An effort was made to determine the amount of timber destroyed by the spruce budworm by applying mortality factors to those areas where some mortality occurred. According to Lachance (1954), the Lower St. LawrenceGaspé areas average 9.5 cords of coniferous trees to the acre; this figure was adopted for our calculations. Since balsam fir constitutes 80 per cent of these stands and the remainder is made up largely of spruce, practically all this coniferous forest is susceptible to budworm attack and indeed was defoliated to some degree between 1949 and 1957. In order to calculate the amount of timber killed by the recent outbreak, it was assumed that an average of 5,18 , and 50 per cent of the coniferous content was destroyed in those areas falling in the mortality categories 1 to 10,11 to 25 , and 26 to 100 per cent respectively. When these mortality factors were applied against the total coniferous content of all areas falling in each mortality category, the estimated volume of timber killed was calculated as $1,400,000$ cords. Part of this dead timber has already been salvaged while another portion is inaccessible and will probably remain so for some time, and cannot be considered as constituting a loss to industry. Had this loss been concentrated in any one sector, the consequences for the limit holders in that sector would have been serious; the fact that mortality was dispersed over such a large territory reduced the impact suffered by individual operators. Because the mortality of greatly weakened trees generally continues for some years after defoliation ceases (Craighead, 1924; Blais, 1958b), it can be expected that more trees will die in 1959 and 1960. Some delayed mortality has already been accounted for in the above figures since they are based on data obtained one year after the last year of severe defoliation; although mortality will continue, it should not be very extensive. The mortality that did occur could largely have been prevented had the spraying operations been practised one or two years earlier.

\section{Estimated Loss Averted Through Spraying}

The amount of wood destroyed by the insect is small compared with what would have been the case had no spraying taken place. In all infested regions in the Lower St. Lawrence and the Gaspé, excepting the region of the Shickshock Mountains, defoliation continued to be severe in unsprayed stands until 1957. Therefore, it can be surmised that the areas that were attacked in, or prior to, 1952 would have been subjected to severe defoliation for six years or more, those attacked in 1953 for five years, and those attacked in 1954 for four years. In all these areas, tree mortality would have occurred in varying degrees and some surviving stands would have become uneconomically exploitable because of extensive mortality in surrounding stands.

On the basis of the known relationship between years of defoliation and tree mortality in other outbreaks (Craighead, 1924; Belyea, 1952; Mclintock, 1955: Blais, 1958b), it can be assumed that in areas where severe defoliation 
would have been continuous for six years or more, for five years, and for four years, 85 per cent, 50 per cent, and 5 per cent of the coniferous forest would have been killed or made unavailable to industry.

The amount of wood that might have been destroyed, had there been no spraying, was calculated on the assumption that defoliation in sprayed areas would have been similar to what it was in unsprayed areas. The number of years in which defoliation would have taken place for each region was based on the interval of time between the first year of severe defoliation (Fig. 1) and the last year, which was 1956 for the region of the Shickshocks, and 1957 for the remainder of the area. Table 3 gives the total area in acres by defoliation category and the estimated loss of wood had there been no spraying. The loss in wood amounts to $14,219,000$ cords, but since an estimated total of $1,400,000$ cords was destroyed in spite of spraying, the volume of wood saved through spraying amounts to $12,819,000$ cords. The total amount of merchantable softwoods for the Gaspé and Lower St. Lawrence was calculated at $54,424,000$ cords by Lachance (1954); the estimated quantity of wood saved through the aerial spraying operations is close to 25 per cent of the softwoods for the whole region, or 42 per cent of the softwoods for the sprayed territories. These estimates are based on average values for the whole region. Since spruce budworm defoliation is usually confined to the more mature stands it is probable that the coniferous content of the affected regions averages more than 9.5 cords to the acre, and that the actual amount of wood saved is probably greater than that calculated.

TABLE 3

Area in Acres That Would Have Been Subjected to Severe Defoliation

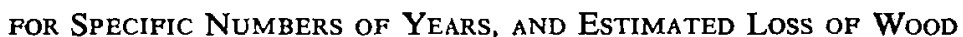
Had There BeEn no Spraying

\begin{tabular}{ccccc}
\hline $\begin{array}{c}\text { Period of } \\
\text { defoliation } \\
\text { in years }\end{array}$ & $\begin{array}{c}\text { Area in } \\
\text { acreg }\end{array}$ & $\begin{array}{c}\text { Total amount } \\
\text { of wood in } \\
\text { cords } 1\end{array}$ & $\begin{array}{c}\text { Estimated } \\
\text { per cent Ioss } \\
\text { of merchantable } \\
\text { wood }\end{array}$ & $\begin{array}{c}\text { Estimated loss } \\
\text { in cords }\end{array}$ \\
\hline 6 or more & $1,215,000$ & $11,546,000$ & 85 & $9,814,000$ \\
5 & 662,000 & $6,292,000$ & 50 & $3,146,000$ \\
4 & $2,650,000$ & $25,180,000$ & 5 & $1,259,000$ \\
\hline Total & $4,527,000$ & $43,018,000$ & & $14,219,000$ \\
\hline
\end{tabular}

'Based on an average of 9.5 cords per acre.

Natural Control Factors Associated with the Decline of the Outbreak

The pre-spray survey was conducted mainly to assist in the timing of operations and the post-spray survey to assess the efficacy of the treatment. These two surveys, however, provided valuable information on populations over wide-spread areas of two critical times in the development of the insect, the early larval stage and the late pupal stage. A comparison of population at these two different times for different years is of some interest (Table 4). Prior to 1956 , pre-spray population surveys were not conducted on a sufficiently large scale to give significant results. Data in Table 4 are based only on those localities that were sampled before spraying and resampled at the time of the postspray survey. 
TABLE 4

Average Number of Insects Per 18-INCH Branch Tip at the Time of the Pre- and Post-Spray Surveys, and the Per Cent Reduction in Population for SPRayed and Unsprayed localities for 1956-58.

\begin{tabular}{llcccc}
\hline Year & \multicolumn{1}{c}{ Treatment } & $\begin{array}{c}\text { Number of } \\
\text { Localitics } \\
\text { Sampled }\end{array}$ & $\begin{array}{c}\text { Av. Number of } \\
\text { Larvae per } \\
\text { 18-inch branch } \\
\text { Pre-spray } \\
\text { (3rd instar) }\end{array}$ & $\begin{array}{c}\text { Av. Number of } \\
\text { Larvae per } \\
\text { 18-inch branch } \\
\text { Post-spray } \\
\text { (pupal stage) }\end{array}$ & $\begin{array}{c}\text { Per Cent } \\
\text { Peelnetion }\end{array}$ \\
\hline 1956 & Unsprayed & 32 & 24.4 & 7.6 & 69 \\
& Sprayed 1956 & 29 & 22.2 & 0.6 & 97 \\
& Sprayed 1955 & 18 & 2.8 & 1.3 & 53 \\
\hline 1957 & Unsprayed & 39 & 20.1 & 2.3 & 89 \\
& Sprayed 1957 & 46 & 27.5 & 0.6 & 98 \\
& Sprayed 1956 & 10 & 10.0 & 2.7 & 73 \\
\hline 1958 & Unsprayed & 64 & 4.2 & 0.18 & 96 \\
& Sprayed 1958 & 40 & 12.2 & 0.41 & 97 \\
& Sprayed 1957 & 26 & 0.5 & 0.01 & 98 \\
\hline
\end{tabular}

There was always a considerable reduction in population between the early larval stage and the pupal stage. In. currently treated localities, the reduction in population was the result of the combined effect of the sprays and of natural control factors, while in untreated localities this reduction was due solely to natural control. There was a gradual increase from 1956 to 1958 in natural control as exemplified by the per cent reduction in population in localities other than in the currently sprayed areas.

The first indication of a population decrease was apparent in the fall of 1956. Until that year, spruce budworm populations had been maintaining themselves at high levels in unsprayed areas and gradually re-invading those that had been sprayed. The effects of the 1956 spring and summer temperatures on spruce budworm populations in the Gaspé Peninsula have been discussed previously (Blais, 1958a) and will only be referred to briefly at this time. In 1956, May, June, July, and August temperatures were considerably below normal, and the spruce budworm was unsuccessful in completing its life-cycle at elevations above 1,800 feet. In the region of the Shickshock Mountains, the eggs were laid mostly in September, four to five weeks later than usual. Many larvae failed to emerge before the onset of the cold fall temperatures. As a result, populations were drastically reduced the following year in a territory extending over 1,600 square miles, or 12 per cent of the area under attack.

In 1957, the summer months were unusually wet, especially July when some precipitation was recorded every day of the month in a number of localities in the Gaspé. The humid conditions were probably responsible for the greatly increased effectiveness of disease in spruce budworm populations that year. Field counts indicated that in some localities up to 60 per cent of the larvae were killed at the time of the sixth instar. A total of nine pathogens were recovered from dead larvae collected from the field. All were known diseases of the spruce budworm that usually do not account for heavy mortality, but, given proper conditions such as existed in July 1957, some of 
them apparently became important mortality factors. Diseases caused by fungi were most prevalent. Of the five species of fungi recovered, Empusa grylli and Sphaerosperma sp. were most common. Bacteria, microsporidia and virus also accounted for some mortality.

The widespread egg-mass survey conducted at the end of August 1957 indicated that populations were very low over 75 per cent of the outbreak area as a result of the combined influence of the cold summer of 1956 and the wet one of 1957.

In 1958, a series of other mortality factors came into play and caused the outbreak to collapse. One of these, although of fair importance, is unknown, but can be suspected of being climatic in nature. Its effects were apparent in a territory of approximately 1,000 square miles in the southeastern sector of the Gaspé Peninsula. Here, populations in the spring of 1958 were not in accord with the high egg-count obtained the preceding summer. Some factor, or factors, had killed a large percentage of the young larvae between the time of their emergence from the egg in August 1957 and their establishment in feeding sites in May 1958. A similar occurrence had taken place over much of the same territory in 1955 , but in this case, the local reduction in insect numbers was only temporary, and populations returned to high levels in subsequent years. In 1958 the event assumed greater importance since it contributed to a further shrinkage of an already greatly diminished outbreak area.

Special investigations on the parasite complex of the spruce budworm in the Lower St. Lawrence and Gaspé were conducted between 1954 and 1958. The data were obtained from a total of 18 widely distributed plots, although no more than 11 were studied in any one year. The detailed findings of these studies were reported elsewhere (Blais, 1960). In summary, aggregate parasitism accounted for about 30 per cent of the spruce budworm population each year between 1954 and 1957. In 1958, however, mortality through parasitism was double that recorded for the past years. This was largely due to the greatly increased action of Meteorus trachynotus (Vier.) and Itoplectis conquisitor Say. Spraying did not appear to have an adverse effect on the parasite complex of the spruce budworm in Quebec.

Predators also assumed much greater importance in 1958 than in previous years. The role played by predators in spruce budworm populations is much more difficult to assess than parasitism. Only indirect evidence of the importance of this factor in 1958 could be gained. In one instance, insects were counted on branches at eye-level on either side of a path running for a total distance of approximately $1 / 4$ mile in a young balsam fir stand. A first count was made on July 15 when 40 per cent of the population was in the pupal, and 60 per cent in the larval stage. During a two-hour period, one observer counted a total of 55 insects which were left in situ. One week later the same observer covered the same ground, and after two hours of diligent searching found one larva and two pupae, while many feeding sites were observed to be unoccupied. Heavy rains and winds sometimes dislodge the larvae from their feeding sites, but in this instance, no rain fell between July 15 and July 22 , and wind velocities were not particularly high. Squirrels and certain species of birds feed upon larvae and pupae of the spruce budworm (Kendeigh, 
1947; Morris et al., 1958). It is probable that at least a portion of the observed population reduction, which amounted to 94 per cent between July 15 and July 22 in the stand under observation, was attributable to predation by birds.

A marked decrease in population between the time of the sixth instar and the pupal stage seems to have been general throughout the outbreak area in 1958. It was noted in particular in eight widely distributed permanent plots used for parasite studies. The average population per 18-inch branch tip for unsprayed plots for collections made at the time of the sixth instar and the time of the pupal stage, and the per cent reduction between the two collections from 1955 to 1958 are shown in the following synopsis:

Population Pler 18-inch Branch Tip

\begin{tabular}{cccc}
\hline Year & $\begin{array}{c}\text { Larvac } \\
\text { (sixth instar) }\end{array}$ & Pupae & Per cent reduction \\
\hline 1955 & 5.8 & 4.3 & 26 \\
1956 & 13.5 & 8.8 & 35 \\
1957 & 5.1 & 3.6 & 30 \\
1958 & 1.5 & 0.3 & 80 \\
\hline
\end{tabular}

In 1958 , populations were much lower, and the reduction between the two collections was considerably greater than for the previous three years. Although the increased action of parasites discussed earlier was partially responsible for this reduction, predators probably accounted for a good share of it.

\section{Discussion and CONCLUSIONS}

The spruce budworm outbreak in the Lower St. Lawrence and Gaspé Peninsula was of sufficient intensity and duration to have resulted in the destruction of very large quantities of pulpwood stands. This was prevented by the extensive spraying operations carried out between 1954 and 1958 in these regions. The chemical control program conducted in New Brunswick and Quebec was not undertaken with the purpose of bringing the outbreak to an end, but rather in an effort to keep under control the damage caused by the insect. This objective was largely achieved. Tree mortality that occurred is insignificant compared with the losses that would have taken place had the outbreak followed its course unchecked.

Because most known infestations of this insect came to an end only after a large proportion of the mature balsam fir stands in the affected regions were destroyed, it was feared, at one time, that spraying might result in the perpetuation of the outbreak by keeping alive trees that otherwise would have been killed. However, such was not the case, and the infestation was brought to an end by natural control factors. Unfavourable weather for two successive summers initiated the population decline, and the collapse of the outbreak was precipitated by the increased action of parasites and predators.

Since the decline of the outbreak was the result of natural control factors and was as evident in unsprayed as in sprayed areas, it may be argued that the spraying operations were not responsible for the collapse of the outbreak. Nevertheless, any factor responsible for the reduction of populations must be considered as having been of some significance during the critical years of 1957 and 1958 when natural control factors were causing severe decreases in spruce budworm numbers. Prior to 1958 , only areas where any 
further defoliation would endanger the life of the trees were treated with DDT. In the spring of 1958 , the area under attack being much reduced, all regions supporting moderate to high spruce budworm populations could be treated with DDT for the first time since the beginning of operations. Although the mortality resulting from the widespread application of insecticides was not responsible for the initial decline, it might, along with certain natural control factors, have influenced the impending collapse of the outbreak.

The experience gained from the extensive aerial spraying operations against the spruce budworm in New Brunswick and Quebec will be of inestimable value in the planning and execution of future operations against forest insect outbreaks, especially those of the spruce budworm. Most of all, any future operations will be undertaken with the knowledge that the damage to the forest by this insect can be forestalled. It must be realized, however, that the circumstances that brought the recent outbreak to an end need not necessarily be repeated, and that although all spruce budworm outbreaks have common attributes, each can be expected to differ from the others in some respects, since the many factors affecting the duration and intensity of outbreaks are so variable. If the forest had not been sprayed, its composition would have been greatly altered through the destruction of much of the mature balsam fir in the Lower St. Lawrence - Gaspé regions. Since this was prevented, the hazard for a spruce budworm outbreak remains, and a second outbreak entirely independent of the first might yet develop in these regions.

\section{ACKNOWLEDGEMENTS}

These studies were made possible through the cooperation of many organizations. The Department of Lands and Forests of the Province of Quebec provided some personnel and transportation facilities for the field work. A number of field assistants was also made available through the courtesy of Quebec Forest Industries Association and much of the aeroplane transportation required for the various surveys was also provided by this organization. A large number of limit holders participated in the egg-survey and furnished useful information in the form of forest inventory maps. The keen interest in this work shown by Dr. L. Daviault, Officer-in-Charge of the Quebec Forest Biology Laboratory, was a source of encouragement.

\section{REPERENCES}

BELYEA, R. M. 1952. Death and deterioration of balsam fir weakened by spruce budworm in Ontario. Part II. An assessment of the role of associated insect species in the death of severely weakened trees. J. For. 50: 729-738.

BLAIS, J. R., and R. MARTINEAU, 1958. Status of the spruce budworm in the Lower St. Lawrence and Gaspé Peninsula at the end of 1958 with special reference to spraying operations. Bi-Mon. Prog. Rept. Div. For. Biol., Dept. Agr. Can. 14 (6): 1-2.

BL.AIS, J. R. 1958a. Effects of 1956 spring and summer temperatures on spruce budworm populations (Choristoneura fumiferana Clem.). Canad. Ent. 90: 354-361.

BLAIS, J. R. 1958b. The vulnerability of balsam fir to spruce budworm attack in northwestern Ontario, with special reference to the physiological age of the tree. For. Chron. 34: 405-422.

BLAIS, J. R. 1960. Spruce budworm parasite investigations in the Lower St. Lawrence and Gaspé regions of Quebec. Canad. Ent. 92:384-396.

COTE, A. 1958. Spruce budworm spraying in Gaspé. Report 38 th Annual Meeting Corporation of Forest Enginecrs for Province of Quebec: 47-55. 
CRAIGHEAD, E. C. 1924. Studies on the spruce budworm (Cacocia fumiferana Clem.) Part II. General bionomics and possibilities of prevention and control. Can. Dept. Agr. Tech. Bull. 37 (n.s.).

GREENBANK, D. O. 1957. The role of climate and dispersal in the initiation of outbreaks of the spruce budworm in New Brunswick. II. The role of dispersal. Can. Jour. Zoology 35 : $385-403$.

HENSON, W. R. 1951. Mass flights of the spruce budworm. Canad. Ent. 83:240.

KENDEIGH, S. C. 1947. Bird population studies in the coniferous forest biome during a spruce budworm outbreak. Ontario Dept. Lands and Forests, Div. of Res., Biol. Bull. 1.

LACHANCE, P. E. 1954. A study of the pulp and paper industry of the Province of Quebec in relation to its present and future wood supplies. Pulp and Paper Mag. of Can. 55: 276-332.

McLINTOCK, T. F. 1955. How damage to balsam fir develops after a spruce budworm epidemic. Northeastern For. Experiment Station Paper 75: $18 \mathrm{pp}$.

MORRIS, R. F. 1954. A sequential sampling technique for spruce budworm egg surveys. Can. Jour. Zoology 32: 302-313.

MORRIS, R. F., CHESHIRE, W. F., MILLER, C. A., and D. G. MOTT, 1958. The numerical response of avian and mammalian predators during a gradation of the spruce budworm. Ecology 39: 487-493.

WEBB, F. E. 1955. Biological assessment of aerial forest spraying against the spruce budwom in New Brunswick. I. Timing of operations 1952-54. For. Chron. 31: 342-352.

WEBB, F. E. 1958. Biological assessment of aerial spraying against spruce budworm in New Brunswick. II. A review of the period 1952-1956. Proc. 10th Int. Congr. Ent., 1956, 4: $525-531$.

WEBB, F. E., MACDONALD, D. R. and D. G. Cameron, 1959. Aerial spraying against spruce budworm in New Brunswick-1958. Bi-Mon. Prog. Rept. Div. For. Biol., Dept. Agr. Can., 15 (1): 1-2.

(Continued from Page 208)

9. MUNNS, E. N. and J. H. STOECKELER, 1946. How are the Great Plains shelterbelts? Jour. Forestry 44: 237-257.

10. NAGEL, C. M. 1949. Leaf rust resistance within certain species and hybrids of Populus. Phytopath. 39: 16.

11. RILEY, G. G. and A. J. SKOLKO, 1942. Resistance to disease in poplar breeding materials. Confidential Report.

12. SKINNER, F. L. 1956. Poplar breeding at Dropmore. Confidential Report.

13. STOUT, A. B. and E. J. SCHREINER, 1933. Results of a project in hybridizing poplars. Jour. Hered. 24: 217-229.

14. VAARTAJA, O. Personal correspondence. 1956-57. 